\title{
Norden, Orienten och Kontinenten i Elsa Lindberg-Dovlettes författarskap
}

ATT RÖRA SIG PÅ GRÄNSEN mellan det bekanta och det främmande är ett balansspel som i en del fall väcker intresse och i andra fall osynliggörs. Elsa Lindberg-Dovlettes (I874-1944) liv och författarskap rör sig i ett sådant gränslandskap. Född i Sverige av finländska föräldrar, sedermera gift med en persisk diplomat och därmed till största delen bosatt utanför Norden har Elsa Lindberg-Dovlette band till flera nationaliteter och kulturer, men hon riskerar samtidigt att inte ha tillräckligt starka band till något av sammanhangen för att betraktas som "en av oss" i varken sina egna eller andras ögon.

Under sin livstid betraktades Lindberg-Dovlette i Sverige och i Finland tillräckligt mycket som "en av oss" för att uppmärksammas i recensioner och press. Det som i första hand väckte mediernas intresse var emellertid det exotiska i hennes liv som persisk prinsessa. ${ }^{1}$

Under de senaste åren har Elsa Lindberg-Dovlettes liv och författarskap varit föremål för ett visst intresse. Även i detta fall är det erfarenheten och skildringarna från Konstantinopel (Istanbul) som har stått i fokus. Anders Hammarlund har i Hugo Alfvénsällskapets tidskrift skrivit om hur Lindberg-Dovlette med hjälp av den svenske kompositören Hugo Alfvén försökte få till stånd en opera baserad

I. Se t.ex. Anna Tuderus, "Elsa Lindberg-Dovlette-Khanoum de Mirza Riza-Khan", Otava I/5 I9I2:5, s. 200-203; Eira Hellberg,"Hos Elsa Lindberg-Dovlette i Monte Carlo", Idun. Illustrerad tidning for kvinnan och hemmet 33, I920:23, s. 393-396, http://hdl.handle.net/2077/41748 (hämtad 22/10 2019); signaturen 'Mukana ollut', "Syksyn vieraita", Naisten Ä̈̈ni XXI, 5 /r2 1926:2I-23, s. 337-340; C - r, "Persiskt. Pennskaftet som blev prinsessa berättar om sina barn och Persiens beslöjade kvinnor", Åbo Underrättelser I2/II I926, s. I-2; Ester Åkesson, ”En intervju med Elsa Lindberg-Dovlette", Våra kvinnor 1926:22, s. 44I-442. 
på musiken och hennes skildringar från Konstantinopel. ${ }^{2}$ Helena Bodin, professor i litteraturhistoria vid Stockholms universitet, har behandlat de av Lindberg-Dovlettes böcker som utspelar sig i Konstantinopel inom ramen för projektet "Cosmopolitan longings and vernacular belongings. Constantinople in literary fin-de-siècle and high modernism". ${ }^{3}$

Någon omfattande undersökning om eller biografi över Elsa Lindberg-Dovlette förekommer inte, men hon ägnas en artikel i Svenskt biografiskt lexikon. ${ }^{4}$ Hennes karriär som journalist före giftermålet bereder henne också en plats i Henrika Zilliacus-Tikkanens När könet började skriva. Kvinnor i finländsk press I77I-I900. ${ }^{5}$

Under signaturen Cric-Cric skrev Elsa Lindberg-Dovlette i flera svenska och finländska dagstidningar fram till att hon 1902 gifte sig med den persiske prins Mirza Riza Khan Arfa-ud-Dovleh (1846-r939). Samma år gav hon ut det första av sina sammanlagt sex skönlitterära verk. År I90I hade hon därtill utkommit med en förkortad

2. Anders Hammarland, "Enleveringen till Seraljen? Elsa Dovlette-Lindbergs möte med Alfvén - 'haremssångerna' kulturhistoriskt belysta", Alfvéniana 2017:3-4, s.4-7,I4-I8, https://issuu.com/alfvensallskapet/docs/alfveniana_redigerad_5 (hämtad 22/10 2019).

3. Helena Bodin, "Mai vite dale svenske", Dragomanen I9, 2017, s. 89-103, http://su.diva-portal.org/smash/get/diva2:Ir85393/FULLTEXTor.pdf (hämtad 22/IO 20I9); Helena Bodin, "Haremslivet i Konstantinopel i berättelser av Elsa Lindberg-Dovlette", Tijdschrift voor Skandinavistiek 36(2), 2018/2019, s. I08-II6, https://www.academia.edu/372IroI5/Haremslivet_i_Konstantinopel_i_berättelser _av_Elsa_Lindberg-Dovlette (hämtad 22/ro 20I9); Helena Bodin,"Seclusion versus accessibility: The harems of Constantinople as aesthetic worlds in stories by Elsa Lindberg-Dovlette", World Literatures: Exploring the Cosmopolitan-Vernacular Exchange, Stockholm: Stockholm University Press 2018, s. 246-26o, https://doi. org/Io.I6993/bat; Helena Bodin, "'The clamour of Babel, in all the tongues of the Levant': multivernacular and multiscriptal Constantinople around 1900 as a literary world", Textual Practice 34, 2020, s. 783-802, https://doi.org/Io.1080/095 0236x.2020.I749382.

4. Sven Erik Täckmark,"Elsa C M Lindberg-Dovlette", Svenskt biografiskt lexikon 23, I980-I98I, s. 259, https://sok.riksarkivet.se/sbl/artikel/Io445, urn:sbl:Io445 (hämtad 22/IO 2019).

5. Henrika Zilliacus-Tikkanen, När könet började skriva. Kvinnor i finländsk press I77I-I90o, Bidrag till kännedom om Finlands natur och folk I65, Helsingfors: Finska Vetenskaps-Societeten 2005. 
sammanställning av sin blivande mans memoarer översatta till svenska med titeln Dagboksblad. ${ }^{6}$

Platser och miljöer från Elsa Lindberg-Dovlettes liv återspeglas i hennes författarskap. Hennes första bok Ann-Lis (1902) utspelar sig i Sverige, likaså första delen av hennes tredje bok En fiolflicka (I910), där handlingen sedan förflyttas till Sankt Petersburg och ut på den ryska landsbygden. ${ }^{7}$ Däremellan utkom Lindberg-Dovlette med sin första bok om Konstantinopel, Kvinnor från minareternas stad (I908). ${ }^{8}$ Hon bodde fem år i Konstantinopel, där hennes man var stationerad som Persiens (Irans) sändebud. På I9ı-talet slog de sig ner i Monaco, som är den plats där de flesta av hennes noveller i samlingen I alla tonarter (I92I) utspelar sig. ${ }^{9}$ I hennes två sista böcker Främling (1924) och Bakom stängda haremsdörrar (I93I) är handlingen igen förlagd till Konstantinopel. ${ }^{10}$

Alla böcker gavs sedermera ut på finska, medan åtminstone de tre första böckerna i ett ganska tidigt skede översattes till nederländska. På tyska utkom alla böcker förutom I alla tonarter och Bakom stängda haremsdörrar, och till franska översattes åtminstone En fiolflicka. Förutom nordiska läsare hade böckerna som utspelade sig i Norden och Konstantinopel alltså en läsekrets som sträckte sig ner till Kontinenten. ${ }^{11}$

6. Elsa Lindberg-Dovlette, Dagboksblad. Memoirer af Prinz Mirza Riza Kahn, [saknar utgivningsort och utgivare] igor.

7. Elsa Lindberg, Ann-Lis. En bok om människors barn, Helsingfors: Söderström \& C:o förlagsaktiebolag 1902; Elsa Lindberg-Dovlette, En fiolflicka. Taflor ur ett människolif, Stockholm: Albert Bonniers förlag rgı。.

8. Elsa Lindberg-Dovlette, Kvinnor från minareternas stad, Stockholm: Albert Bonniers förlag 1908 .

9. Elsa Lindberg-Dovlette (prinsessa Mirza Riza Khan), I alla tonarter. Noveller, Stockholm: Albert Bonniers förlag I92I.

Io. Elsa Lindberg-Dovlette (prinsessa Mirza Riza Khan), Främling. Boken från Konstantinopel. Historier om Astrid-Anisa, Condjagull och Yasmine, Stockholm: Albert Bonniers förlag 1924; Elsa Lindberg-Dovlette (prinsessa Mirza Riza Khan Arfa), Bakom stängda Haremsdörrar, Stockholm: Albert Bonniers förlag I93I.

II. På finska: Elsa Lindberg-Dovlette, Anna-Liisa,Helsinki: Kirja 1926; Elsa LindbergDovlette, Naisia minareettien kaupungista, Helsinki: Kirja I926; Elsa LindbergDovlette, Viulutyttö, Helsinki: Kirja 1926; Elsa Lindberg-Dovlette, Kaikissa sävellajeissa, Helsinki: Kirja 1926; Elsa Lindberg-Dovlette, Haaremin ristikon takaa: pohjoismaalainen nainen itämaalaisen puolisona, Helsinki: Kirja 1925; Elsa LindbergDovlette, Häät Bosporin rannalla: Haaremin ristikon takaa 2, Helsinki: WSOY 1932. 
I denna essä studerar jag övergripande och återkommande teman och drag i Elsa Lindberg-Dovlettes författarskap som helhet och hur hon relaterar till dem via tre referensmiljöer som jag har benämnt efter mönster från hennes samtid - Norden, Orienten och Kontinenten.

Orienten representerar föreställningen och författarens framställning av den miljö i Sydvästasien och Nordafrika som också refereras till som Mellersta Östern och Främre Orienten. I Elsa LindbergDovlettes fall koncentreras miljöskildringen mera specifikt till kulturen bland i första hand den muslimska befolkningen i Konstantinopel före första världskriget och Kemal Atatürks moderniseringprogram, samt till de persiska traditioner som upprätthölls och förmedlades via Lindberg-Dovlettes make.

Kontinenten och Norden går delvis in i varandra i och med att de representerar kristendom, Europa och västerlandet, medan Orienten står för österlandet. I Elsa Lindberg-Dovlettes författarskap går det ändå i vissa fall att hitta en distinktion mellan Norden och det som här sammanfattas som Kontinenten. Norden står för föreställningen om och författarens framställning av de nordiska ländernas kultur, samhälle, klimat och folk, färgade av protestantisk kristendom. Kontinenten representerar "den stora världen", det kosmopolitiska, vad gäller moral, rikedom och anrika europeiska kulturmiljöer. Samtidigt står det för katolsk men även ortodox kristendom, och såväl Sankt Petersburg, Paris och Franska rivieran som den kristna befolkningen i Konstantinopel omfattas av kontinentalbegreppet.

På tyska: Elsa Lindberg-Dovlette, Ann-Lis - ein Buch von Menschenkindern, Leipzig: [utgivare okänd] 1903; Elsa Lindberg-Dovlette, Konstantinopel-aus dem Tagebuch einer jungen Türkin, Berlin: [utgivare okänd] I9ı6; Elsa Lindberg-Dovlette, Frauen aus der Stadt der Minarette, Berlin: [utgivare okänd] 1926; Elsa Lindberg-Dovlette, Eine Geigerin - Bilder aus eine Menschenleben, Berlin: [utgivare okänd] I918; Elsa Lindberg-Dovlette, Der Gesang der dunklen Wasser - ein Buch von Konstantinopel, Berlin: [utgivare okänd] I927. På nederländska: Elsa Lindberg-Dovlette, Zijn melodie, Utrecht: [utgivare okänd] 1920; Elsa Lindberg-Dovlette, Vrouwen uit de minarettenstad, Utrecht: [utgivare okänd] I9ı6; Elsa Lindberg-Dovlette, Viola - schilderingen uit een menschenleven, Utrecht: [utgivare okänd] I9r6. På franska: Elsa Lindberg-Dovlette, Un violon chanta - roman, Paris: [utgivare okänd] 1926. 


\section{Med PENNAN SOM PENSEL}

"Förf[attare]ns penna tyckes snarare doppad i färgtuber än i bläck", är ett av de recensionsuttalanden om Elsa Lindberg-Dovlettes debutbok Ann-Lis som citeras i hennes följande böcker. Redan då hon gett ut sin första bok associerar recensenterna, inte bara i Stockholms Dagblad, hennes sätt att skriva med en målares arbete. I Nordisk Tidskrift lyder omdömet:

Man går fram genom boken såsom genom ett galleri af taflor, än med kraftiga, djärfva penseldrag gjorda, än utförda med miniatyrmålningens hela finess i detaljer. Förf[attare]n ser allting så lifligt framför sig, som om hon sutte och målade efter naturen. Men det är verkliga konstverk hon ger. Det är med en verklig konstnärsblick hon ser och skildrar. Ann-Lis lofvar mycket, men den ger också redan. ${ }^{12}$

I novellsamlingen I alla tonarter ingår en novell om fadern, violinisten Johan Lindberg. I minnestexten skildrar Lindberg-Dovlette första gången hon upplevde ett slags kallelse att skriva. Hon erinrar sig en kväll som flicka när hon i sin säng i gränslandet mellan dröm och verklighet genom sin fars fiolspel får en inblick i konstens storslagenhet:

Den lilla flickan lyssnar betagen och en oändligt stor lycka vidgar hennes bröst. Ty bakom de slutna ögonlocken ser hon tusende syner och sköna bilder burna till henne av tonvågorna. För första gången erfar hon ett behov av att beskriva och sammanställa det hon ser, för första gången känner hon förmågan att uppfatta det sköna och återgiva det just efter sin tro och måla det $\mathrm{i}$ ord, så att även andra kunna se och förstå vad hon hört och tänkt därvid. ${ }^{13}$

I romanen En fiolficka tar Lindberg-Dovlette fasta på sitt erkänt måleriska berättarsätt och ger boken undertiteln Taflor ur ett människolif. I alla sina böcker tenderar hon att "måla" miljöer och scener som antingen placeras efter varandra och bildar en sammanhängande berättelse, eller så bildar tavlorna enskilda berättelser som i novellsam-

I2. Se omdömena om Elsa Lindberg-Dovlettes tidigare verk på nästsista bladet i Lindberg-Dovlette, Kvinnor från minareternas stad; Lindberg-Dovlette, En fiolficka. Kursiv i boken.

I3. Lindberg-Dovlette, I alla tonarter, s. I22. 
lingen I alla tonarter och i Kvinnor från minareternas stad, där läsaren får följa enskilda personer på olika håll i Konstantinopel. Det hon vill åstadkomma är att läsaren ska "känna" berättelsen:

Den, som vill veta, hur Konstantinopel riktigt noga ser ut och lära sig en massa namn, som alltid af främlingar dock uttalas oriktigt, den, som vill ha fakta och årtal, den bör skaffa sig en Bædeker [känd reseguideboksserie] och läsa sida efter sida och tro och vara nöjd. Men om någon vill känna en helt svag liten fläkt från det orientaliska Konstantinopel - det undanträngda, som steg för steg drager sig tillbaka in i Asien, hvarifrån det kommit, nu långsamt, men säkert förtärdt af greker, armenier och franker - då kan han kanske finna något däraf i de små spridda blad, som Djamilé Hanoums gamla amma samlat i en broderad duk, som doftade af rosenolja och jasmin. ${ }^{14}$

I Elsa Lindberg-Dovlettes måleriska berättarstil utgör de nordiska, orientaliska och kontinentala inslagen färger på hennes palett när hon målar fram stämningar, miljöer, människokaraktärer och teman. Därtill ger hon målande detaljstudier av olika etniska folk- och samhällsgrupper, raser och nationaliteter. I synnerhet berättelsernas bifigurer får ofta representera folklynnen eller nationalkaraktärer snarare än unika personligheter. Hennes samtids intresse för och vana att kategorisera personer utifrån typiska egenskaper för ras, etnicitet, religiös eller kulturell tillhörighet framstår i dag, efter 1900-talets dåliga erfarenheter av rastänkande som dragits till sin spets, i ett mera problematiskt ljus.

\section{ETT INSTÄNGT OCH UTSATT KVINNOGALLERI}

Kvinnor är oftast huvudpersoner i Elsa Lindberg-Dovlettes berättelser. Påfallande många är moder-, fader- eller helt föräldralösa, vilket ger författaren litterär frihet att försätta protagonisterna i utmanande omständigheter. Lindberg-Dovlette verkar upptagen av vad som händer när en person tvingas ut ur sin bekvämlighetszon. I Ann-Lis konstaterar hon att ingen vet något om dygd som inte prövats: "Låt någon af de omvårdade rosorna växa som vildrosen. Om 'de dygdiga

I4. Lindberg-Dovlette, Kvinnor från minareternas stad, s. 3-4. Kursiv i originalet. 
kvinnorna' skulle pröfva det samma som de af samhället fördömda, kanske skulle de sjunka än djupare."15

De utmanande omständigheterna medför utsatthet kombinerad med ett lösare förhållande till samhälleliga ramar och regler. Faderns död möjliggör i den inledande berättelsen i Kvinnor från minareternas stad att Djamilé Hanoum ${ }^{16}$ kan fungera som ciceron, eller dragoman som guiderna och tolkarna kallades i Konstantinopel. Tidigare bodde hon i sin far, Emin Paschas vita yali (större lanthus) vid Bosporens strand, där hon genom sin franska guvernant och engelska miss får en europeisk uppfostran men samtidigt lever den orientaliska högreståndskvinnans instängda liv. När fadern dör flyttar hon in hos en gammal tant högst uppe på den högsta av den muslimska stadsdelen Stambouls sju kullar, endast åtföljd av sin trogna amma Rubabie. Som en följd av att hon går miste om överdådet som anstår en paschafamilj öppnar sig Konstantinopel med dess basarer och Validehbron för Djamilé Hanoum, och genom henne också för den "främmande" västerländska läsaren. ${ }^{17}$

Ann-Lis som namngett Elsa Lindberg-Dovlettes första roman är moderlös. Hennes far, herr Hans von Gyllen, bereder henne genom sitt adelskap en aktad samhällsställning men berövar henne genom sitt supande alla ekonomiska möjligheter att leva ståndsmässigt. Det rena och oskuldsfulla i hennes karaktär framhävs av det ljust nordiska i hennes utseende. Även huvudpersonen i En fiolflicka, den moder- och i praktiken också faderlösa Viola, som av alla kallas Fiola, har blont hår och blå ögon, likaså den svenska Astrid-Anisa som i Främling och i uppföljaren Bakom stängda haremsdörrar konfronteras med det orientaliska haremslivet när hon som hustru till en turkisk pascha anländer till Konstantinopel.

Som kontrast till Ann-Lis tjänar den brunögda och mörkhåriga, moderlösa Mariatta, med italienskt påbrå och därmed förknippad med kontinental sydländskhet. Medan Ann-Lis framställs som god men utsatt för onda omständigheter - hennes utmaning är att komma över sin stammande blyghet och sitt obemötta kärleksbehov som präglat

15. Lindberg, Ann-Lis, s. 300-301.

16. Det osmansk-turkiska ordet hanoum betyder ungefär fru eller härskarinna.

I7. Lindberg-Dovlette, Kvinnor från minareternas stad. 
hennes av medberoende fyllda barndom - balanserar Mariattas uppenbarelse mellan gott och ont. I Mariattas överdådiga salong finns en skulpterad karmstol av svart ebenholts som speglar hennes karaktär:

Och ur träverket grina hornprydda faunhufvuden bredvid leende änglaansikten. Armstöden äro svarta änglavingar utbredda till flykt. Men benen äro krumma bockben, och den svarta hofven märker sin afbrutna ring skarpt in uti isbjörnshudens hvita. ${ }^{18}$

I slutet av boken bekänner Mariatta:

Halft var all - - Aldrig hade jag varit riktigt ond - - men aldrig heller riktigt god. - - Det jag ville hafva, det hade jag tagit, tröttnade jag på det, gaf jag det igen. När jag var barn, gällde det grannlåt, när jag blef vuxen, blef det människohjärtan.$---{ }^{19}$

I Främling och i Bakom stängda haremsdörrar ställs den mörka och orientaliska Yasmine som motsats, och uttalad konkurrent, till den ljusa och nordiska Astrid-Anisa. Yasmine har som liten lämnats till paschans familj, som i trohet mot Allah är skyldig att ta hand om henne. Som äldre får hon ansvaret för den unge paschans rum och blir hans kalfa (föreståndarinna) med uppgift att klä honom och se till hans behov, och om han visar tecken också dela hans bädd. Som odalisk eller haremskvinna är Yasmine inte en hustru: "men kunde bliva det med tiden, om hon fick ett barn och visade sig värdig", vilket både hon och paschans mor hoppas på. ${ }^{20}$

Från den nordiska mytologin använder Elsa Lindberg-Dovlette faunen för att symbolisera ondska och onda makter, medan "onda ögat" fyller motsvarande funktion i Orienten. Innan den nygifta AstridAnisa och paschan anländer till Konstantinopel söker Yasmine upp en kvinna som ger henne pulver och besvärjelser som ska locka paschan till henne och lägga en förbannelse på Astrid-Anisa så att den nygifta aldrig blir annat än en främling i paschans hus. ${ }^{21}$

I8. Lindberg, Ann-Lis, s. 156 .

I9. Ibid., s. 308 .

20. Lindberg-Dovlette, Främling, s. 78-9г.

2I. Ibid., s. IO8-I28. 
I avsnittet "Den svarta och den hvita skogen" i Kvinnor från minareternas stad förekommer inte en lika klar favorisering av det ljusa framför det mörka. I detta fall är det snarare kombinationen av de två som lyfts fram. Lindberg-Dovlette kallar Konstantinopel staden av de två skogarna - "den svarta och den hvita - cypressernas och minareternas stad", en syn som också möter Astrid-Anisa när hon i Främling anländer till staden. "Orientalens fatalism” har lett till att ställen som utsatts för brand inte byggs upp på nytt, vilket resulterar i att områden med djupt svartgröna cypresser reser sig lite varstans i staden. Lika höga reser sig den vita skogen av moskéernas minareter. En blandning av det svarta och vita är den unga och behagliga "mulatten" Fisse som är gift med en gammal muezzin (böneutropare). Muezzinens ålder har gjort både hans hår och skägg lika vita som minareterna, som han blivit ett med. I en dröm får muezzinen en uppenbarelse om att han ska göra en pilgrimsresa till Mecka för att be Allah skänka honom en son. Under tiden inkvarterar sig Fisse i en paschas yali där hon på obestämd tid gör sig hemmastadd på orientaliskt vis, utan att ha starka kopplingar till ägaren. I yalins trädgård arbetar"negern" Hassan och som en naturens oundviklighet dras han och Fisse till varandra i nattens mörker. När den ovetande muezzinen återvänder får han inom kort bönesvar i form av att Fisse föder honom en svart son. På vägen upp till utropstornet pendlar muezzinen mellan stolthet, sorg och förhoppning tills han når toppen av minareten: "Då lyftes inom honom en oändlighet af idel tacksamhet, och från hvita skogens öfversta topp tackar han Allah för barnet från svarta skogen." 22

"Den svarta och den hvita skogen" är den berättelse i Kvinnor från minareternas stad som slutar lyckligast för den kvinnliga huvudpersonen. I de övriga berättelserna slutar det med död eller hopplöshet när kvinnorna sträcker sig efter något mer än en behaglig tillvaro med mat och husrum, med den enda uppgiften att finnas till för sin man, som antingen är ålderstigen eller ung och frånvarande. Trots ansatsen att för läsaren måla upp den exotiska Orienten är det övergripande intrycket kvinnornas instängdhet. Instängdheten ser man i husens inhägnade trädgårdar och kvinnornas del av husen, harem eller

22. Lindberg-Dovlette, Kvinnor från minareternas stad, s. 63-90. Kursiv i originalet; Lindberg-Dovlette, Främling, s. 168. 
haremlika, med sina gallerförsedda fönster som hindrar insyn men också begränsar kvinnornas möjlighet att tillägna sig omvärlden. $\mathrm{Om}$ de turkiska kvinnorna tillåts röra sig utanför hemmet åker de rika i vagnar täckta med träluckor försedda med ett litet titthål i form av ett hjärta, och alla klär sig i den heltäckande och oformliga tjartjaffen ${ }^{23}$, även läsarens dragoman Djamilé Hanoum:

Kom med mig du, min främmande vän! Jag får ej taga din arm, ty det passar sig ej för en muhammedansk kvinna att gå arm i arm med någon. Jag får ej tala högt på gatan och aldrig vända på hufvudet. Genom mitt svarta flor är jag skild från allt och alla. Och allting blir fjärran för mig som bakom en sorgeslöja. Ty att skåda genom ett svart flor är som att se på allt genom tårar. Du kan möta röda och gula, och blå och gröna tjartjaffer, men alltid är det svarta floret där som en mörk fläck i all färgglädje.

Men jag är glad åt, att du ej får skåda under allt detta svarta gas. Du skulle blott blifva nedstämd kanske för alla de bleka ansikten, du mötte och för alla de sorgsna, bruna ögon, som skulle se på dig.

Det är bättre så. - Vi skyla våra ansikten och glida skygga i skuggan af våra moskéer likt mörka fantomer. Ty vår underbara stad är $\mathrm{i}$ sig själf nog soligt skön och leende och färgrik för att undvara den kvinnliga skönheten. ${ }^{24}$

I Djamilé Hanoums ord är det sannolikt främst författarens röst som hörs. I Främling och i Bakom stängda haremsdörrar är det nordiska Astrid-Anisa som gör motsvarande anmärkningar och har svårt att anpassa sig till instängdheten, medan resten av haremet med paschans mor, syster och hela raden av tjänarinnor inte ifrågasätter sitt sätt att leva. ${ }^{25}$

Livet i den unge paschans yali vid Bosporens strand utgör handlingen i Främling, där maktkampen mellan Astrid-Anisa och Yasmine är den huvudsakliga intrigen. Avskildheten både avskärmar och skyddar kvinnorna från männens värld. Husets herre, den unge

23. Carşaf, en heltäckande slöja eller kappa för kvinnor som blev vanlig under Abdülhamid II:s styre kring sekelskiftet I900, som en reaktion mot västerländskt inflytande.

24. Lindberg-Dovlette, Kvinnor från minareternas stad, s. 22-23. Kursiv i originalet.

25. Lindberg-Dovlette, Främling; Lindberg-Dovlette, Bakom stängda haremsdörrar. 
paschan, är den ende som har tillgång till haremet. I Bakom stängda haremsdörrar når en mans brutalitet in i kvinnornas skyddade värld genom giftermål. Boken handlar om förberedelserna och bröllopet mellan den unge paschans syster Condjagull och den gamle, rike och härsklystne Neriman-Pascha. Som ung har Condjagull drabbats av blindhet, vilket familjen beaktar när de överväger hennes möjligheter på äktenskapsmarknaden. Hon är Astrid-Anisas förtrogna i haremet och också den person i berättelsen som framstår som renast och mest oskuldsfull. ${ }^{26}$

Ett motsvarande giftermål med en gammal, både fysiskt och till sitt uppförande motbjudande man erbjuds Ann-Lis när hennes nya styvmor gör klart för henne att alla pengar inte längre kan gå till hennes utbildning. Ann-Lis bestämmer sig för att försöka undkomma Holta-Jöns äktenskapsanspråk genom att försörja sig som lärarinna och läxhjälp och sedan sällskapsdam, medan hon samtidigt förbereder sig för studentexamen. ${ }^{27}$

I novellerna från Monte Carlo i I alla tonarter finns alltid kasinot där i bakgrunden och både lockar och fördärvar stadens unga kvinnor. Glamouren och lyxen har sin charm, tillsammans med drömmen om lättförtjänta pengar. Kvinnornas lycka och olycka är ändå inte beroende av spel, utan av män som är villiga att lägga sina pengar på dem. ${ }^{28}$

Trygghet och frihet kan ses som motsatta poler, men är i bästa fall som två sidor av samma mynt. Den som är trygg kan känna sig fri och den som är fri kan känna sig trygg. Ifall omgivningen upplevs för beskyddande eller tar sig för stora friheter kan tryggheten och friheten omvandlas till instängdhet och utsatthet, vilket på olika sätt är fallet för kvinnorna i Elsa Lindberg-Dovlettes böcker. I böckerna från Konstantinopel tenderar kvinnorna att vara utsatta i sin instängdhet, medan utmaningen på Rivieran och även i de nordiska förhållandena är att kvinnorna upplever sig vara instängda i sin utsatthet.

26. Lindberg-Dovlette, Bakom stängda haremsdörrar.

27. Lindberg, Ann-Lis, s. I24-I49, I62-I79.

28. Lindberg-Dovlette, I alla tonarter, s. $\mathrm{I}_{5} \mathrm{I}-227$. 


\section{KONSTENS KÖTT OCH SJÄL}

Utöver föräldralöshet använder Elsa Lindberg-Dovlette konstvärlden som ett sätt att tvinga huvudpersonerna ut ur det bekanta och bekväma. För Lindberg-Dovlette var miljön inte främmande. Hennes far Johan (Jean) Lindberg var violinist och professor vid Kungliga Musikkonservatoriet i Stockholm. Modern Emilia (f. Wiik) var pianist, medan systern Sigrid Lindberg var en begåvad violinist. Moster var konstnären Maria Wiik. ${ }^{29}$ Konst i olika former är ett återkommande element i hennes böcker, i synnerhet i Ann-Lis och i En fiolflicka som i huvudsak skildrar nordiska förhållanden.

Även om handlingen utspelar sig i Norden eller personerna kommer därifrån har konstvärlden en kontinental prägel. Paris finns där som referenspunkt och modell för det konstnärliga livet. Skulptören Leo Thelmar som huvudpersonen Ann-Lis förälskar sig i åker, i likhet med många av de nordiska konstnärerna kring sekelskiftet I90o, upprepade gånger till konstmetropolen. Fiola i En fiolflicka bereds också möjlighet att under en vistelse i Paris fördjupa sina musikstudier. Det är också i Paris den turkiske paschan och Astrid-Anisa har lärt känna varandra i Främling och i Bakom stängda haremsdörrar. I En fiolflicka tjänar Sankt Petersburg som kosmopolitisk miljö och inte heller Stockholm undgår i Ann-Lis "den stora världens" sviktande moral. ${ }^{30}$

För kvinnor framstår Lindberg-Dovlettes konstvärld som en miljö där de är utsatta, där framgång eller hoppet om framgång gör att de förväntas acceptera ett slags demimondeställning ${ }^{31}$ i vilken männens fysiska närmanden ses som ett nödvändigt ont. Ann-Lis väninna Mariatta som söker sig till teatern äcklas men kan på samma gång inte låta bli att lockas av männens uppmärksamhet. Under sin tid på teaterskolan blir hon vittne till hur en herreman söker sig till en operettsångerskas klädloge och mannen sniket borrar sina fingrar in i "det mjuka, varma kvinnohullet" på sångerskans arm:

29. Täckmark, "Elsa C M Lindberg-Dovlette".

30. Lindberg, Ann-Lis, s. 190-282; Lindberg-Dovlette, En fiolflicka, s. 99-224; Lindberg-Dovlette, Bakom stängda haremsdörrar, s. 6o-65.

3I. Om uttrycket demimonde, se Elisabeth Stubb, "Edelfelts värld: Demi-Monde", SLS-bloggen I4/3 20I7, https://www.sls.fi/sv/blogg/edelfelts-varld-demi-monde (hämtad 22/IO 20I9). 
Hon [operettsångerskan] ryser lätt. Men hon sitter alldeles stilla, gör icke en rörelse ens. Hon endast småler samma stereotypa leende, som kröker hennes rödmålade mun till en stel halfbåge, liksom hos komedins hålögda mask. ${ }^{32}$

Det påklistrade leendet tvingar sig också Fiola till ett par gånger i En fiolflicka. På båten till Sankt Petersburg träffar hon på musikkritikern och kompositören doktor von Wullt, som erbjuder sig att hjälpa fram henne i karriären:

Han flyttade sig närmare intill henne. Och hon fick en förnimmelse af, att när han såg på henne, var han henne så nära, att hon helst velat stiga upp och gå bort med händerna för ögonen.

Men det gällde ju hennes karriär som artist. - Det hörde väl till då och det måste väl vara så. - Hon drog sig så långt in i sitt lilla hörn hon kunde, men smålog på samma gång uppmuntrande mot honom och kände förstulet efter, om de små artistlockarna vid öronen voro, just som de borde vara. ${ }^{33}$

Fiola förmår slutligen inte hålla fast vid det uppmuntrande småleendet utan sliter sig loss. Det samma händer när hon i sin förtvivlan över sin obefintliga karriär en kväll går med på att följa med doktor von Wullts sällskap till öarna där Sankt Petersburgs förnämsta varietélokal och utevärdshus Akvarium finns. ${ }^{34}$ Där är Fiola inte den enda som vrider sin mun till ett småleende. De uppträdande romska kvinnorna har ett visst skydd av att röra sig i grupp:

Det finnes bland dessa unga zigenerskor, som tränga sig fram arm i arm, en och annan, som är så vacker, att man endast blir att stirra på henne. En melankolisk, vild skönhet, där allt är stora, svarta ögon och en brännande, röd mun. Blir någon af dem fasthållen vid axeln af någon af publiken, låter hon sig smekas. Hon står alldeles stilla, visar blott sina hvita tänder likt ett litet tämjdt vilddjur, men släpper

32. Lindberg, Ann-Lis, s. 57-64, 88.

33. Lindberg-Dovlette, En fiolflicka, s. I2I-I22.

34. Ibid., s. I63-I95. 
ej kamraternas armar. Och blir hon bjuden att sitta ned vid bordet, drager hon också de andra flickorna med. ${ }^{35}$

Elsa Lindberg-Dovlette beskriver också i Bakom stängda haremsdörrar hur kvinnor som grupp kan fungera som projektionsyta för manliga fantasier i orientalisk tappning. På Condjagulls och Neriman-Paschas bröllopsdag bjuds den ålderstigne brudgummen och de manliga gästerna på underhållning i selamlik, männens avskilda del av huset. I revy passerar en syrisk trollkarl, en japansk jonglör, en akrobatisk "ormmänniska" och gycklande dvärgar. Föreställningen kulminerar i sex undersköna alméer ${ }^{36}$ anförda av Rihana från Bagdad - "Den blå näktergalen", följd av tre moriska dansöser:

Hennes [en av dansösernas] ansikte är obeslöjat och dock tyckes det mer hemligt, än om det vore dolt av en slöja. Men det underbara är, att man kan få det att uttrycka, just det man önskar. Kanske därför, att det i sig själv ej äger något uttryck, utan antager för stunden det, som man helst vill tro att det äger. [...]

Men äro deras ansikten uttryckslösa, så tala deras kroppar alla tre samma ohöljda språk - erbjudandets erotiska förklaring - en kärlekssång i rörelser - en pantomin, som ropar högt utan ord.

Vid paschornas bord är det ingen som äter mer - - - ${ }^{37}$

Lindberg-Dovlette återkommer till den orientaliska dansen i "Den svarta och den hvita skogen" i Kvinnor från minareternas stad där Fisse dansar för sin man, muezzinen, för att göra honom vänligt inställd innan hon tänker lägga fram sin anhållan om att få ett gult tyg hon sett i ett butiksfönster. ${ }^{38}$ Astrid-Anisas rival Yasmine väntar också på tillfällen att framföra sin dans för den unge paschan i Främling: "Men mest av allt gav hon sig hän till dansen - den orientaliska, som pekar ut, talar om och visar fram var för sig - ett efter ett - allt det, som kvinnan annars dygdesamt döljer." ${ }^{39}$

35. Ibid., s. I78.

36. Egyptiska dansöser, sångerskor eller musiker av hög kvalitet.

37. Lindberg-Dovlette, Bakom stängda haremsdörrar, s. I6I.

38. Lindberg-Dovlette, Kvinnor från minareternas stad, s. 72-74.

39. Lindberg-Dovlette, Främling, s. 85. Kursiv i originalet. 
Förutom att det i konstvärlden väcks ensidiga eller ömsesidiga köttsliga lustar kan denna värld i unika ögonblick ta sig själsligt gudomliga uttryck. I minnestexten över fadern Johan Lindberg beskriver Lindberg-Dovlette ett sådant tillfälle:

Men det är en hög, ren sopranton, som knyter samman de sista tongångarna. Och när alla andra toner förklingat i de skymningstunga valven, då jublar ännu denna enda klingande ton i obunden frihet däruppe i domens högsta kupol närmast stjärnorna, likt en själ, som frigjord höjer sig till Gud. ${ }^{40}$

Renheten i Ann-Lis väsen inspirerar skulptören Leo Thelmar till det han tror kan bli mästerverket i hans karriär och även han närmar sig det själsligt gudomliga. Hon får honom att tänka på ett 'andante religioso ${ }^{41}$ - "allvarligt kyskt och oskyldigt". Här använder Elsa Lindberg-Dovlette en liknande beskrivning som i minnestexten över fadern. Ann-Lis påminner om en länge ljudande orgelton:"[d]en, som är mild och klar och löper lindande len och lefver ännu länge i ljust pianissimo där uppe i kyrkans högsta, solfyllda hvalf, sedan de andra tystnat i mörkret där nere." 42

Leo Thelmar förmår Ann-Lis att stå modell för honom i "jungfrulig nakenhet" och skulpturen väcker konstkännarnas gillande:

Kropp och kött har han gifvit oss förr, han, vår Leo Thelmar, och vi ha varit glada åt honom, därför att hans kvinnor voro så kraftigt jordiska. [...]

Men hon den lilla här, hon kunde ej röras vid med händerna - var intet för sinnena - och man tänkte inte på henne så. Subtil var hon som en blomma och skygg som en fågel och sval och mjuk som en våg, men rörelsen $\mathrm{i}$ hela hennes unga kropp var sång - --

Ja, hon är Melodin, musikens gudomliga själ och genom henne är Leo Thelmar en stor man $-{ }^{43}$

40. Lindberg-Dovlette, I alla tonarter, s. I2I-I22.

4I. Musikterm: långsamt gående tempo spelat med andakt.

42. Lindberg, Ann-Lis, s. 215.

43. Ibid., s. 250-25r. Kursiv i originalet. 
En manlig konstnär är föremål för Ann-Lis kärlek, liksom även för Fiolas i En folfficka. Även om männen genom sin konst når gudomliga höjder är de luttrade av"den stora världen" när det handlar om kvinnor. Leo Thelmar deklarerar att en konstnär inte kan ha två kärlekar, konsten och kvinnan. Han har valt konsten, vilket inte hindrar honom från att försöka förföra Ann-Lis. Innan han når sitt mål inträffar emellertid en vändpunkt när han inte längre är den som vill mest, utan hon. Leo Thelmar lăter sig uppslukas av arbetet med sitt konstnärliga mästerverk samtidigt som han försöker lösgöra sig från Ann-Lis, som drabbas av en alltuppfyllande kärlek som inte lämnar henne någon stolthet kvar. Leo Thelmar är för "honnett" för att dra nytta av hennes kärlekstörst, men släcker allt hopp om en gemensam framtid:

"Man skall inte hålla af någon så som du." Hans röst är så knapp och torr."Man träffas - - har nöje af hvarandra och sen -- -

Man måste vara själfvisk för att komma fram här i världen och bli till något. Egoism kallas egentligen bara det, som är hvars och ens människorätt. Men det är inte alla, som ha kraft att häfda den - - " 44

Ann-Lis kämpar för att hålla fast vid Leo Thelmar till den grad att han känner sig tvungen att verbalt smutsa ner det rena:

"Vill du, att jag skall ropa ut för alla, att du stått modell för mig - Är det - - det du vill - - naken modell - - Vill du också, att jag skall skrika högt ut - att du inte var så svår att öfvertala - - du - - som mången flicka från gatan, som jag betalade för hennes kropp - - "

Då växer hon inför honom i den höghet, som rena tankar förläna. Och det är glans omkring henne.

- - Hade hon icke mottagit detta som en sällsynt utmärkelse - Att få vara den, efter hvilken en konstens odödliga skapelse skulle bära dragen! - - Hon hade gifvit sig hän åt det som åt något stort, - - något att vara stolt öfver - - något, som kunna gifva innehåll åt ett helt lif. Då hon stod blottad inför honom, hade hon känt det, som om genom ateljéens genomskinliga glashvalf själfva himlen såg ned därpå---

Så talar hon.

44. Ibid., s. 278-279. 
Och i det ögonblicket känner han, att det är han, som är liten. Men hon var stor $--_{-45}$

Även kompositören Obilensky i En fiolficka förklarar för Fiola konstnärens oförmåga att älska en kvinna. Obilensky har emellertid börjat tänka på sitt eftermäle. Hans kompositioner och symfonier fyller inte behovet han känner: han vill ha en son av sitt kött och blod, och han vill att Fiola ska vara sonens mor. Han gör klart för henne att det inte är fråga om kärlek:

Han talar till henne hela tiden på franska och äfven Fiola svarar honom på detta böjliga, mjuka språk, såsom han vill det - - - Non - - non - - je ne t'aime pas - - -" säger hon efter hans önskan. [...] Och i samma ögonblick tänker hon vid sig själf. - - Mitt hjärta förstår ej franska. - Ty aldrig, aldrig skulle hon på sitt eget modersmål kunnat svara - - Jag älskar dig ej - -" [...]

Då böjer han sig ned och kysser henne - - - "Min sons mor - min sons mor," upprepar han. Och åter kysser han henne.

Men Fiola skälfver i hans famn. Och hon tänker vid sig själf - - Så kysste han ändock aldrig mig själf $-{ }^{46}$

Den böjliga franskan, som till skillnad från modersmålet gör det möjligt att förtränga det sanna, understryker konstvärldens kontinentala prägel. Om det är det nordiska, kontinentala eller orientala, eller alla tre, som bereder rum för konstnärliga storverk förblir oklart. Däremot präglas den luttrade synen på mellanmänsklig kärlek och lust av influenser från "den stora världen". Förutom att konstvärlden låg Lindberg-Dovlette nära ger den henne möjlighet att försätta personerna hon skriver om i situationer där de tvingas ut från det medelmåttiga och bekväma. De prövas till sin yttersta gräns. Frågan är om de slår ut i blom eller vissnar av erfarenheten.

45. Ibid., s. 28r. Kursiv i originalet.

46. Lindberg-Dovlette, En fiolficka, s. 223-224. 


\section{Korset, Madonnan OCH HALVMÅnen}

"Tror du inte, [...], att de största öfverraskningarna äro de, som ens egen natur bereder en?" frågar Ann-Lis apropå påståendet att det inte går att veta något om en dygd som inte prövats. ${ }^{47}$ Den repliken sätter ord på vad Elsa Lindberg-Dovlette verkar vilja att hennes protagonister ska nå fram till - att de om så bara för ett ögonblick får känna att de är i kontakt med sin sanna natur, sin själ. Det är en dygd som inte definieras av samhälleliga ramar för hur dygden ska ta sig uttryck, utan avser en naturlig längtan, djupare än civilisationens fernissa, efter det som är sant och äkta. Förutsättningarna att nå fram till, och framför allt bevara, sin naturs innersta väsen ter sig olika beroende på vilken referensmiljö Lindberg-Dovlette placerar handlingen i, gemensamt däremot är att dygden prövas av kärlek och lidande.

I Elsa Lindberg-Dovlettes första och tredje bok Ann-Lis och En fiolficka märks allra tydligast denna röda tråd, att förbli ren och sann mot sin natur eller själ, och där får berättelsen den mest hoppfulla upplösningen. Den optimistiska tilltron och idealismen kanske beror på att de hör till hennes första böcker och hon inte har luttrats av livet. Kännetecknande är åtminstone att författaren behandlar detta genomgående tema utifrån en nordisk-protestantisk referensram, som präglas av direkta hänvisningar till Gud och Kristus utan inblandning från helgon eller andra förmedlare.

Efter Leo Thelmars hårda ord känner sig Ann-Lis smutsig för att hon stått nakenmodell och samtidigt kan hon inte ta sig ur den alltuppslukande obesvarade kärleken. Räddningen blir mötet med fröken Malm, som övergett den egoistiska kärleken för att helt ägna sig åt den utgivande kärleken, den kärlek som utgår från att ge snarare än från att få, genom att driva ett hem för kvinnor - "barnamörderskor, tjufvar och kvinnor som sålt sig på gatan”. Ann-Lis ber fröken Malm att också hjälpa henne att återvinna aktningen för sig själv och sedan låta henne hjälpa till i arbetet. För kvinnorna på hemmet ger Ann-Lis en lektion som kulminerar i en lovsång till kvinnan som Guds skapelse:

47. Lindberg, Ann-Lis, s. 3 or. 
Det fagraste i världen är kvinnans kropp. Skapelsens krona är hon -- Guds tempel, formad kärleksfullt af hans heliga hand. Och därför skall hon vara kysk - - vara utan vank och fläck, ty inom henne skall blifva den ädlaste, lifsalstrande förening - - -

- - Hon är den hvita jungfrublomman, i hvars famn mänsklighetens dyrbara frukter skola mogna [...]

En procedur, känd in i alla orena detaljer af alla dessa dömda kvinnor, men gjord så vacker som ett under nu af denna unga flicka, som aldrig burit ett barn på sina smala armar. ${ }^{48}$

Efter den amorösa kärlekens tillkortakommanden är det moderskärleken som slutligen firar triumfer. Ann-Lis väninna Mariatta vill efter att hon blivit mamma lära sig godhet och inser vilken god man hon har i sin make, som hon tidigare negligerat. Ann-Lis drabbas ännu av längtan efter sin enda kärlek Leo Thelmar och sörjer att hon aldrig kommer att bli mor. Det var när hon som barn fick vara som en mor för sin försupne far som hon kände den renaste kärleken. Det var när Leo Thelmar vädjade till hennes moderskänslor som hon öppnade sig för kärleken till honom. $\mathrm{Nu}$ är hon omgiven av kvinnor som också kallar henne "lilla mor". Boken slutar med orden: "Men till henne komma tankar - - stilla - - milda - - Hon var ju dock - - mor - 'lilla mor' for människors barn". ${ }^{49}$

I En fiolflicka känner sig Fiola mera ambivalent inför moderskapet. I äktenskapet med Obilensky är hon reducerad till mor för hans son, medan hon längtar efter att bli älskad som hustru. Hon kan inte låta bli att känna avundsjuka mot sin ofödde son, som är föremål för Obilenskys kärlek. ${ }^{50}$

Som barn växte Fiola upp på "den gamla gatan" i Stockholm, där var och en av invånarna gav henne insyn i olika dimensioner av musikens väsen. Mest drogs hon till den sorgsna "Kattjungfrun", som lärde henne att den som har musiken i sin själ kan spela fram sin sorg i mörka toner:

48. Ibid., s. 304, 306 .

49. Ibid., s. 3II-3I2. Kursiv i originalet.

50. Lindberg-Dovlette, En fiolflicka. 
Ty vill du spela till dig människors håg och sinne. Då måste du gifva dig själf i utbyte. Du måste lära dig älska stort och lida gränslöst. Ty det är detsamma. Då skall din fiol lära sig sjunga ut stora, underbara toner och icke blott noter. Ty noter äro svarta punkter på linjeradt papper. Men toner äro oändlighetens fria ljusbarn. ${ }^{51}$

En pusselbit som hjälper henne på vägen att hitta musiken i sin själ får Fiola när hon går in i ett ryskt kapell i Sankt Petersburg. Det är inte ortodoxins guda-, madonna- eller helgonbilder Fiola dras till, utan till en bild med två sorgsna Kristusögon. Hon blir betagen av ögonens "underbara, förstående lidande" och i sitt inre hör hon en underbar tolkning av stycket Wienarwskis Legende. Hon hör allt mänskligt elände sammanfattas i styckets glidande skala, för att i avslutningen erbjudas förlåtelsen i blid försoning. ${ }^{52}$

När Fiola får möjlighet att framföra Wienawskis Legende för doktor von Wullts sällskap på Akvarium spelar hon inte längre bara noter, men det är inte Kristusbildens tolkning som besjälar henne. I stället förbyts framförandet i passion och djupa toner där den glidande skalan uttrycker kärlekens berusning och förintelse: "Och den sista klagosucken, mildrad af sordinen, blef nu trånad efter det, som världen har att bjuda." Trots att hjärtat slår sprängande hårt och vilt av framförandet är hon på samma gång besviken: "Är det detta man kallar att lefva?" 53

Än en gång är det Kristusgestalten som räddar Fiola från artistlivets krassa villkor. I en dröm finner hon ro och stillhet när hon möter Kristus med de sorgsna ögonen, bärande på ett litet lamm, från vars bröst det droppar blod. I drömmen byts Kristus ut mot Obilensky och hon påminns om hans ord till henne:"Man bör aldrig underhandla med sig själv, blott handla". Han har sett hennes ovilja att kompromissa med sig själv och därigenom något av hennes själ. På grund av drömmen är Fiola redo att bli hans hustru, även om det

5I. Ibid., s. $48-49$.

52. Ibid., s. I46-I47. Wienawskis Legende eller Légende op. 17 för violin och piano är ett existerande musikstycke från 1859 av den polska violinisten Henryk Wieniawsky. Henryk Wieniawsky och hans bror Józef var duktiga musiker som turnerade flitigt i Europa i mitten av i8oo-talet.

53. Lindberg-Dovlette, En fiolficka, s. 184, 186. Kursiv i originalet. 
till hennes besvikelse bara är för att bli mor till hans barn. Slutligen är det sonen som ger kärlekens gåva, genom att offra sig själv, som ett blödande lamm. Pojken är dödfödd och Fiola tror att hon är den enda som sörjer honom. Sonens död har emellertid fött kärlek till henne i Obilenskys hjärta, han är redo att erkänna kärleken till en kvinna. Han vill därtill höra henne spela Beethovens konsert, som han tidigare påstått att hon inte förstår att spela förrän hon genomgått och luttrats av sorgen i livet. Nu är hon redo för både Beethoven och Kattjungfruns "trollåt" som föds ur stor kärlek och gränslöst lidande: "Du skall spela den med hela din själ, ty din själ är skön." ${ }^{4}$ Boken är tillägnad Lindberg-Dovlettes far, som enligt minnestexten i I alla tonarter också kunde "trolla", vilket Lindberg-Dovlette i det sammanhanget förklarar med att han var"finne": "Och det är ju känt att finnar kunna trolla." ${ }^{55}$

I novellerna i I alla tonarter präglas livet i Monaco av två krafter, kasinots fläkt av"den stora världen" och katolicismens inflytande i form av Madonnan, Jesus mor Maria. Även om personerna i novellerna ser på Madonnan med vördnad, förhåller sig Elsa Lindberg-Dovlette mera avvaktande. I den inledande novellen"Den lilla madonnans stora underverk" får läsaren följa en madonnabilds resa genom tiden från Italien till Monte Carlo, där konstverket slutligen hamnar i ett kapell på lyxhotellet Riviera Palace, som under första världskriget tjänade som krigssjukhus för Röda Korset. Under resan är det flera personer som upplever att de blir hjälpta av Madonnan, medan författaren för varje under ger en rationell förklaring. ${ }^{56}$

Det mirakel Elsa Lindberg-Dovlette ändå tillskriver Madonnan är moderskärlekens under; boken är tillägnad Lindberg-Dovlettes mor. I den inledande novellen söker sig en fransk mor som sjuksköterska till krigssjukhuset. Hon har förlorat sin son i kriget och som patient dyker den tyske officer som tog livet av sonen upp. Modern är fast besluten att hämnas sin son, men Madonnan i kapellet får henne på andra tankar och hon vårdar officeren så att han överlever. Ett brev till den tyske officerens mor avslutar hon med orden:

54. Ibid., s. 203-204, 26I-278.

55. Lindberg-Dovlette, I alla tonarter, s. I02. Kursiv i originalet.

56. Ibid., s. 5-43. 
Dödens mörka skugga har glidit över Frankrike. Minnet av våra döda kan ej utplånas. Deras namn skola skrivas på marmortavlor, men det är i mödrarnas hjärtan de äro djupast inristade ...

I Frankrike och Tyskland är det vi mödrar, som lida mest. Och den, som lidit mycket, kan kanske även en gång förlåta ... ${ }^{57}$

I böckerna som utspelar sig i Konstantinopel utgör klyftan mellan kristna och muslimer den mest avgörande uppdelningen mellan Kontinenten och Orienten. Elsa Lindberg-Dovlette låter något starkare än det instängda livets bekvämlighet väckas i två av sina muslimska huvudpersoner, Sakhra och Scheker-Bulih, i Kvinnor från minareternas stad, vilket får dem att sträcka sig efter en kristen man. Priset är högt. De stängs ute från sina hem. Scheker-Bulih dör av köld på en bänk, Sakhra tvingas ut i Konstantinopel på egen hand, utblottad efter att hon gett alla sina pengar åt den kristne levantinsk-grekiske kaikroddaren som är ovetande om att hon förälskat sig i honom. ${ }^{58}$

Klyftan mellan muslimer och kristna är lättare att överbrygga när kvinnan är kristen och mannen muslim, vilket är fallet med AstridAnisa och den unge paschan i Främling. Detta är möjligt eftersom den svenska Astrid som gift förlorar sin gamla nationalitet och identitet; hon får namnet Anisa och förväntas leva som en muslimsk hustru. Redan i inledningen av Främling definierar Elsa Lindberg-Dovlette ramarna för det turkiska hushållet: "'Att vilja' - det är för mången detsamma som att bliva åtlydd. - 'Att lyda' - det är för mången detsamma som att inte alls hava någon vilja mer. // I turkiska hus är det en som vill och många som lyda." ${ }^{59}$

Det är husets herre, vars vilja blir åtlydd i de turkiska hemmen, vilket Astrid-Anisas rival Yasmine vet att anpassa sig till och använda till fullo. På väggen i den unge paschans sovrum finns en bild, vars text personifierar Yasmines sätt att försöka fånga paschans hjärta:"Så länge som ordet härskare finnes på människornas läppar - - så länge som ordet slav ej ännu är försvunnet i världen - - - så länge skall $d u$ vara min bärskare och jag din hängivna slav - - ". ${ }^{60}$

57. Ibid., s. $42-43$.

58. Lindberg-Dovlette, Kvinnor från minareternas stad.

59. Lindberg-Dovlette, Främling, s. 8. Kursiv i originalet.

6o. Ibid., s. 90 . Kursiv i originalet. 
Främling är den bok där mötet och krocken mellan Norden/Kontinenten och Orienten lyfts fram som ett huvudtema. Den nordiska Astrid-Anisa anländer till paschans hus, västerländskt vag i sitt gudsförhållande, men alltid med ett kors om halsen under kläderna. Korset skyddar mot Yasmines försök att kasta "onda ögat" på henne. En kulturkrock som Lindberg-Dovlette återkommer till upprepade gånger finns mellan "västerlänningens oro" och "orientalens fatalism". Skillnaden framhävs redan när Astrid-Anisa och den unge paschan bestämmer sig för en gemensam framtid: "Hon - lycklig och orolig på engång, han - lugn som den, som vet, att allt, som sker är förutbestämt - ont som gott och att intet av ödet utstakat kan undvikas." ${ }^{61}$ Noteras kan att det som anger tonen för Elsa Lindbergs översatta urval av hennes blivande makes memoarer i Dagboksblad är Mirza Riza Khans konstaterande: "Jag är fatalist och hyser en blind tro på ödet och mina drömmars förvärkligande."62

Till skillnad från Elsa Lindberg-Dovlette och Mirza Riza Khan som hade en åldersskillnad på nästan trettio år, är Astrid-Anisa och den turkiske paschan båda unga. Främling är tillägnad LindbergDovlettes son, prins Ibrahim Arfa-ul-Mulk, som växt upp med en nordisk mor och en persisk far till största delen i Monaco. Främling slutar med att den unge paschan ställs inför ett val. Valet står inte i första hand mellan Astrid-Anisa och Yasmine, utan i att han över huvud taget beslutar sig för att välja. I Lindberg-Dovlettes framställning av Orienten ingår uppfattningen att en hustru och en tjänarinna/ odalisk inte utesluter varandra, medan en man i västerländsk tappning förväntas göra ett val mellan dem.

Främling avslutas med åtminstone en delseger för Astrid-Anisa. Hon har sökt sig bort från sitt rum i förtvivlan över att Yasmine som tjänarinna än en gång är den som väntar uppe och möter paschan när han kommer hem från kvällens fester. Paschan söker emellertid upp Astrid-Anisa och förebrår henne milt för hennes västerländska egensinnighet som tvingar honom att välja. Han meddelar henne att han har sänt bort Yasmine från sitt rum och att han väljer Astrid-Anisa. ${ }^{63}$

6I. Ibid., s. 54. Se även s. I7-I9. Kursiv i originalet.

62. Lindberg-Dovlette, Dagboksblad, s. 4.

63. Lindberg-Dovlette, Främling, s. 280-284. 
I uppföljaren Bakom stängda haremsdörrar återkommer LindbergDovlette till klyftan mellan "västerlänningens oro" och "orientalens fatalism". För att förbereda Condjagull för bröllopet med NerimanPascha har modern förklarat att hon ska tänka på den blivande maken som en far och en bror, och Condjagull önskar sig inget mer än en kysk kyss på pannan. Modern drabbas under Condjagulls bröllopsnatt av oro över vad familjen har lett dottern in $i$, men låter sig lugnas av sin tjänarinna:

"Den styrande handen är Allahs; vi äro blott medlet", då var det som
om ansvaret till stor del flyttades bort från mänskliga skuldror. Och
den gamla modern och hennes tjänarinna kände ansvarslöshetens
stora vila omkring sig. [...]
Men det fanns ännu någon i den gamla yalin, vars alla tankar sökte
den lilla bruden. Och hon var Västerlandets oroliga dotter [Astrid-
Anisa], som dömde sig själv och kände ansvarets tyngd trycka sig. ${ }^{64}$

Condjagulls bröllopsnatt slutar i endast en kyss på pannan, i och med att Neriman-Pascha kallas bort på ett brådskande uppdrag för sultanen. Under hans frånvaro tas hon om hand av sin nye personlige eunuck Firouz-Agha, och kärleken väcks till liv: "För första gången kände Condjagull, att hon inom sig ägde en makt, mycket starkare än allt annat, till och med än sin egen känsla av rätt och orätt och det var kvinnomakten." Condjagull som berövats sin syn och eunucken Firouz-Agha som berövats sin manlighet utvecklar under tre dagar en omöjlig kärlek som får sitt slut när Neriman-Pascha återvänder och fullbordar äktenskapet med våld. ${ }^{65}$

Elsa Lindberg-Dovlettes tendens att skildra kvinnor som kommer i kontakt med sin innersta natur, om än bara för en flyktig stund och till kostnaden av att älska stort och lida gränslöst, ger kanske en förklaring till den kryptiska sista meningen i hennes sista bok. Condjagulls handlingskraftiga tjänarinna tar Condjagull tillbaka till hennes barndomshem, där hon slutligen dränker sig i yalins rum med instängt vatten:"Och det levande, instängda vattnet hade varit hennes

64. Lindberg-Dovlette, Bakom stängda haremsdörrar, s. 220-22I.

65. Ibid., s. 224-3I7. 
tröst. // Ty en enda natt hade varit nog för henne att luttras genom lidandet. // För mången annan är ej ens ett helt liv tillräckligt."66

\section{BindeSTRECKSIDENTITET OCH DRAgOMAN}

Litteraturvetaren Helena Bodin skriver om Elsa Lindberg-Dovlette som en bindestrecksidentitet, sammansatt av svenskt och orientaliskt, vilket illustreras av det dubbla efternamn hon tar efter giftermålet. Lindberg är hennes flicknamn, medan Dovlette är en variant av makens namn Dovleh. Bodin påpekar att bindestrecket kan ses inte bara som ett emblem för föreningen av skilda nationaliteter, utan det kan också beteckna glidningen mellan kategorier såsom det välkända och främmande, och det kvinnliga och manliga ${ }^{67}$

Grovt indelat representerar Ann-Lis och den inledande delen av En fiolflicka det nordiska, medan fortsättningen på En fiolflicka och novellsamlingen $I$ alla tonarter skildrar en kontinental motsvarighet. I de tre böckerna förlagda till Konstantinopel får läsaren i sin tur bekanta sig med en orientalisk miljö.

Indelningen är emellertid inte så kategorisk och statisk som läsaren vid en första anblick kan förledas att tro. Inom de litterära världar som Lindberg-Dovlette målar fram förekommer oftast inslag också från de andra kulturella kontexterna hon rör sig i, men som inte utgör den huvudsakliga miljön $\mathrm{i}$ ifrågavarande berättelse. I de böcker som exempelvis utspelar sig i Norden förekommer kontinentala och orientaliska inslag. Inslagen kan utgöras av konkreta föremål, företeelser eller personer som i texten förknippas med Norden, Orienten eller Kontinenten. Därtill förekommer det att författaren intar en förklarande och tolkande roll för sina (nordiska/kontinentala) läsare där hon speciellt i böckerna som utspelar sig i Konstantinopel betonar hur saker ter sig ur västerländsk och österländsk synvinkel. Slutligen tillkommer Lindberg-Dovlettes egna uppfattningar och de övergripande teman hon behandlar i sina berättelser.

66. Ibid., s. 224-317.

67. Bodin, "Haremslivet i Konstantinopel i berättelser av Elsa Lindberg-Dovlette", s. Io9. 
Den roll Elsa Lindberg-Dovlette intar som författare skulle jag snarast vilja likna vid en dragoman, tolkarna som ofta var en nödvändighet för att besökare över huvud taget skulle kunna kommunicera och klara sig i Konstantinopels språkliga och kulturella myller. ${ }^{68}$ I de litterära världar som Lindberg-Dovlette skapar är läsaren förstås utlämnad åt författarens framställning. Även om dragomanerna hade insyn i, kunskap om och erfarenhet av den kulturella mångfalden hade de en speciell förståelse för och favoriserade gärna sitt eget ursprung. I Elsa Lindberg-Dovlettes böcker skymtar också en mera inkännande framställning av de nordiska inslagen fram, och större förutsättningar att för mer än en kort stund komma i kontakt med sin natur.

Helena Bodin reflekterar kring det kryptiska slutet på Elsa Lindberg-Dovlettes sista bok Bakom stängda haremsdörrar, där en natt hade varit nog för Condjagull "att luttras genom lidandet", medan för många andra inte ens ett helt liv är tillräckligt:

Här når med ens berättarens ord ut ur romanens estetiska värld och vittnar genom uttrycket 'för mången annan' om kvinnors livslånga lidande. Berättelsernas sagokaraktär och genretypiska voyeurism får här stå tillbaka för den feministiska agendan, eller rör det sig snarare om resignation, kanske till och med om förtvivlan å kvinnornas vägnar? ${ }^{69}$

I ljuset av de övergripande temana i Lindberg-Dovlettes samlade skönlitterära verk framstår det inte som att lidande är kvinnornas största problem. Både i nordiska, kontinentala och orientaliska förhållanden öppnar stor kärlek upp för gränslöst lidande, men det är värt det om det för en i kontakt med ens själ och natur. Trots Lindberg-Dovlettes utförliga skildringar av kvinnors utmanande omständigheter verkar ändå de som lever sina liv i ytlig bekvämlighet, men går miste om den djupare "kvinnomakten" som Condjagull för ett kort ögonblick kom i kontakt med, dra det kortare strået. Är det detta som ”mången annan” får tillbringa ett helt liv utan att uppleva?

68. Se Helena Bodin, "Konstantinopel kring I90o som litterär värld", Tidskrift för litteraturvetenskap 48, 20I8:I-2, s. 52 .

69. Bodin, "Haremslivet i Konstantinopel i berättelser av Elsa Lindberg-Dovlette", s. II4. 